\title{
Estudio por DRX del efecto de adiciones de aluminatos y ferritos en la formación de silicatos bicálcicos
}

\section{DRX study of the effects of aluminates and ferrites additions over bicalcium silicates formations}

\author{
F. TRIVIÑO VÁZQUEZ y S. ORTEGA \\ ICCET/CSIC/ESPAÑA
}

Fecha de recepción: 14-V-90

\section{RESUMEN}

Estudio por DRX de los efectos de las adiciones de ferritos y aluminatos sobre la formación de los silicatos bicálcicos, por medida de las alturas de los picos indicados en los difractogramas de los componentes: $\mathrm{CaO}, \mathrm{SiO}_{2}, \beta-\mathrm{C}_{2} \mathrm{~S}, \gamma-\mathrm{C}_{2} \mathrm{~S}, \mathrm{C}_{3} \mathrm{~A}, \mathrm{C}_{2} \mathrm{~F}$ y $\mathrm{C}_{4} \mathrm{AF}$, para estudiar sus influencias mutuas y las de los aluminoferritos sobre dichos silicatos bicálcicos, obtenidos a partir de distintos crudos. Los conocimientos adquiridos se pueden utilizar para saber los efectos parciales de dichos componentes en la fabricación de clínker portland.

\section{SUMMARY}

It must be measured the height that is obtained in the peaks indicated in the diffractograms of the compounds: $\mathrm{CaO}, \mathrm{SiO}_{2}, \beta-C_{2} \mathrm{~S}, \gamma-C_{2} \mathrm{~S}, \mathrm{C}_{3} \mathrm{~A}, \mathrm{C}_{2} \mathrm{~F}$ and $\mathrm{C}_{4} A F$, with the finality of study their mutual influences, and also study the aluminoferrites over such bicalcic silicates, obtained from differents raw mix.

The adquired knowledges can be used to know the partial effects of such components in the elaboration of portland clinker.

\section{INTRODUCCIÓN}

En los clínkeres de cemento portland es necesario saber la influencia de los distintos óxidos: $\mathrm{CaO}, \mathrm{SiO}_{2}, \mathrm{Al}_{2} \mathrm{O}_{3}$ y $\mathrm{Fe}_{2} \mathrm{O}_{3}$ en la capacidad de formación y de estabilidad de los polímorfos $\beta$ y $\gamma$ del silicato bicálcico $y$, también, en la cantidad y relación de los silicatos bicálcicos formados; dicha cantidad influirá en la alita formada.

Desde hace varios años se han estudiado los polimorfos del silicato bicálcico, especialmente las formas $\beta$ y $\gamma$, por muchos autores $e$ investigadores (referencias 1 a 6 ), y también, en ocasiones, la influencia del hierro y de la alúmina (7).

Los márgenes estudiados por los autores de este trabajo son estrechos en concentraciones molares y no se dan los difractogramas, sino los resultados de determinados picos que simplifican el estudio. Como se sabe la cal reacciona con la cristobalita, en la cual se convierte el cuarzo, para dar gamma silicato bicálcico en un principio $y$, posteriormente, y a mayores temperaturas, aparece la forma beta

\section{INTRODUCTION}

For the portland cement clinkers it is necessary to know the influence of the different oxids: $\mathrm{CaO}, \mathrm{SiO}_{2}, \mathrm{Al}_{2} \mathrm{O}_{3}$ and $\mathrm{Fe}_{2} \mathrm{O}_{3}$ with the capacity of formation and the stability of the polimorfus beta and gamma of bicalcic silicate and also with the quantity and relation of the bicalcic silicates obtained; such quantity will have influence with the alita obtained.

From several years; has been studied the polimorfus of bicalcic silicate especially the beta and gamma forms, by many authors and investigaters, also, when it has been necessary (1 to 6) we have studied the influence of the Fe and the alumina (7).

The limits that have been studied for us are very little in molar concentrations, we don't give the difractogrames, but we give the results of determinated peaks that makes eausier the study. As it is known the lime reacts with the cristobalite which is transformed in quartz to give bicalcic silicate gama in first place and later, with higher temperature; it appears stable 
del silicato bicálcico, estable a temperatura ambiente, que después y si hay suficiente cal reaccionará dando origen a la alita.

En el estudio por DRX del $\beta-C_{2}$ S se utiliza el pico $31^{\circ}$, de poca intensidad $=34$, así como un factor de conversión de 2,38 que multiplica a las intensidades obtenidas por la forma $\beta$, para obtener resultados comparables con los de la forma $\gamma$ que tienen más intensidad $=80$.

\section{PREPARACIÓN DE LAS MUESTRAS}

La composición de los crudos se calculó para adiciones de 5, 10, 15 y 20 partes de aluminatos $\mathrm{y} / 0$ ferritos cálcicos a 100 partes de silicato bicálcico. Se utilizaron reactivos MERCK en forma de gel de sílice, carbonato cálcico, óxido de aluminio y óxido de hierro. Las mezclas se homogeneizaron en un mortero mecánico de ágata y se pastillaron en forma de discos a una presión de $240 \mathrm{~kg} / \mathrm{cm}^{2}$. Posteriormente se calentaron en crisoles de platino a las temperaturas indicadas en las gráficas, en el eje de abscisas. at the temperature of the medium, the beta form of the bicalcic silicate, later if there is enough lime will reacto to give alita.

For the study by $D R X$ of the $\beta-C_{2} S$ it is used the peak for $31^{\circ}$, of little intensity $=34$ to obtained results that you can compare with those that have the gamma form, which that have more intensity $=80$, than it used a conversion factor of 2,38 that multiplies the obtained intensities for the beta form.

\section{PREPARATION OF THE SPECIMEN}

The composition of the crudes was calculated for additions of $5,10,15$ and 20 parts of calcium aluminates and/or calcium alumina ferrites at 100 parts of bicalcium silicate. They were used MERCK reactives in form of: silica gel, $\mathrm{CaCO}_{3}, \mathrm{Al}_{2} \mathrm{O}_{3}$ and $\mathrm{Fe}_{2} \mathrm{O}_{3}$. The mixture was made homogeneously with the use of a mechanical agate mortar and so they were obtained tablets with the form of disk and was used a presion of $240 \mathrm{~kg} / \mathrm{cm}^{2}$; after that they were heated during 20 minutes into platinum crucibles at the temperature that are indicated in the graphics (abscissa axis).

TABLA 1

Identificación de componentes (Compounds identification)

\begin{tabular}{|c|c|c|c|c|}
\hline Compuesto (Compound) & $\begin{array}{l}\text { Formula } \\
\text { (Formula) }\end{array}$ & $\begin{array}{c}\text { Carta } \\
\text { (Charte) }\end{array}$ & $\begin{array}{l}2 \varnothing \text { utilizado para } \\
\text { ánodo de cobre } \\
\text { ( } 2 \varnothing \text { to anode } \\
\text { copper used) }\end{array}$ & $\begin{array}{c}\text { Intensidad } \\
\text { del pico } \\
\text { (Peak intensity) }\end{array}$ \\
\hline $\begin{array}{l}\text { Cuarzo bajo } \\
\text { [Low quartz (S)] }\end{array}$ & $\mathrm{SiO}_{2}$ & $5-490$ & 26,04 & 100 \\
\hline $\begin{array}{l}\text { Cristobalita baja } \\
\text { (Low cristobalite) (S) }\end{array}$ & $\mathrm{SiO}_{2}$ & $11-695$ & $21,92,849$ & 100 \\
\hline $\begin{array}{l}\text { Ferrito bicálcico } \\
\text { (Bicalcium ferrite) }\left(C_{2} F\right)\end{array}$ & $\mathrm{Ca}_{2} \mathrm{Fe}_{2} \mathrm{O}_{5}$ & $19-222$ & 33,33424 & 100 \\
\hline $\begin{array}{l}\text { Brownmillerita } \\
\text { (Brownmillerite) }\left(C_{4} A F\right)\end{array}$ & $\mathrm{Ca}_{4} \mathrm{Al}_{2} \mathrm{Fe}_{2} \mathrm{O}_{10}$ & $30-226$ & 33,879 & 100 \\
\hline $\begin{array}{l}\text { Aluminato tricálcico } \\
\text { (Tricalcium Aluminate) }\left(C_{3} A\right)\end{array}$ & $\mathrm{Ca}_{3} \mathrm{Al}_{2} \mathrm{O}_{6}$ & $31-300$ & 27,557 y 27,695 & 100 \\
\hline $\begin{array}{l}\text { Cal } \\
(\text { Lime) (C) }\end{array}$ & $\mathrm{CaO}$ & $4-777$ & 53,844 & 44 \\
\hline $\begin{array}{l}\text { Gamma silicato bicálcico } \\
\text { (Gamme bicalcium silicate) }\left(\gamma-C_{2} S\right)\end{array}$ & $\gamma-\mathrm{Ca}_{2} \mathrm{SiO}_{4}$ & $31-297$ & 29,677 & 80 \\
\hline $\begin{array}{l}\text { Larnita sym. } \\
\text { (Sym. larnite) }\left(\beta-C_{2} S\right)\end{array}$ & $\beta-\mathrm{Ca}_{2} \mathrm{SiO}_{4}$ & $9-351$ & 31,074 & $34\left(^{*}\right)$ \\
\hline
\end{tabular}

(*) Su intensidad se multiplica por $2,38=80$ para compararla con la forma gamma.

(It intensity was multiplicated by $2,38=80$ to compare it with the gamma form).

\section{INFLUENCIA SOBRE LOS SILICATOS DE LA ADICIÓN DE FERRITOS $\mathrm{Ca}_{2} \mathrm{Fe}_{2} \mathrm{O}_{5}$}

Las gráficas de la cal nos indican, en función de la altura del pico, intensidad y temperatura

\section{INFLUENCE ON THE SILICATES BY ADITION OF FERRITES $\mathrm{C}_{2} \mathrm{Fe}_{2} \mathrm{O}_{5}$}

The CaO graphic (Fig. CaO) indicates us, in function of the peak hight, intensity and 
que la cal ha reaccionado en mayor cantidad y más rápidamente con la sílice, cuanto más baja sea la intensidad y menor la temperatura a que aparezca el pico.

El aumento de concentración en el crudo de $\mathrm{Ca}_{2} \mathrm{Fe}_{2} \mathrm{O}_{5}$ de 5 a 15 por cada 100 de $\mathrm{Ca}_{2} \mathrm{SiO}_{4}$ influye en la velocidad de reacción con la sílice. En la cristobalita y silicatos cálcicos cuanta más intensidad, y a menor temperatura aparezca el pico de la sílice o del silicato, hay mayor formación de éste. Así sucede con la cristobalita (S) a $1.205^{\circ} \mathrm{C}$ para las tres adiciones de ferritos; las de $15 \mathrm{Ca}_{2} \mathrm{Fe}_{2} \mathrm{O}_{5}$ son ligeramente más elevadas (Fig. 1, S), la intensidad de la cristobalita disminuye a $1.320^{\circ} \mathrm{C}$, por formarse con la cal a dicha temperatura $\gamma-\mathrm{Ca}_{2} \mathrm{SiO}_{4}$ (Fig. $1, \gamma-\mathrm{C}_{2} \mathrm{~S}$ ), las cantidades detectadas de este compuesto son muy similares, aunque ligeramente mayores para la adición de 15 de $\mathrm{Ca}_{2} \mathrm{Fe}_{2} \mathrm{O}_{5}$. Al aumentar la temperatura a $1.434^{\circ} \mathrm{C}$ no se detecta el $\gamma-\mathrm{Ca}_{2} \mathrm{SiO}_{4}$; la disminución en el pico de la $\mathrm{CaO}$ a esta temperatura (Fig. $1, \mathrm{CaO}$ ), se explica por la formación de $\beta-\mathrm{Ca}_{2} \mathrm{SiO}_{4}$, estable a temperatura ambiente; también influye en la formación de $\mathrm{Ca}_{2} \mathrm{Fe}_{2} \mathrm{O}_{5}$, según se puede apreciar en la Figura $1, \beta-C_{2} S$ y $C_{2} F$ ), este último es proporcional en su formación a la cantidad calculada en el crudo y a la elevación de la temperatura (1 a 7). temperature, that lower is the intensity and less temperature appears the peak, it is because the $\mathrm{CaO}$ has reaccionated in larger cantity and greater velocity with the silica. In the cristobalite (Fig. 1, S) and calcium silicates when greater intensity and less temperature appear the $\mathrm{SiO}_{2}$ or silicate peak it is that, there is greater formation of this. So takes place with the cristobalite (S) at $1.205^{\circ} \mathrm{C}$ for the three aditions of ferrites, the $15 \mathrm{Ca}_{2} \mathrm{Fe}_{2} \mathrm{O}_{5}$ were ligtly greater (Fig. 1, S) the intensity of the cristobalite diminishes to $1.320^{\circ} \mathrm{C}$ to form with the $\mathrm{CaO}$ at such temperature $\gamma-\mathrm{Ca}_{2} \mathrm{SiO}_{4}$ (Fig. 1, $\gamma-C_{2} \mathrm{~S}$ ), the detected quantities of this compound are very similar, although lightly greater for the addition of $15 \mathrm{Ca}_{2} \mathrm{Fe}_{2} \mathrm{O}_{5}$. When the temperature increases to $1.434^{\circ} \mathrm{C}$ the $\gamma-\mathrm{Ca}_{2} \mathrm{SiO}_{4}$ is not detected the diminution of the peak of $\mathrm{CaO}$ at this temperature (Fig. CaO) is explained by the formation of $\beta-\mathrm{Ca}_{2} \mathrm{SiO}_{4}$, stable at the ambient temperature, also has influence in the formation of $\mathrm{Ca}_{2} \mathrm{Fe}_{2} \mathrm{O}_{5}$ as you can see in the graphics (Fig. 1, $\beta-\mathrm{C}_{2} \mathrm{~S}$ and $\mathrm{C}_{2} \mathrm{~F}$ ) later $\mathrm{Ca}_{2} \mathrm{Fe}_{2} \mathrm{O}_{5}$ in its formation at the calculated quantity into the crude and at the temperature elevation.

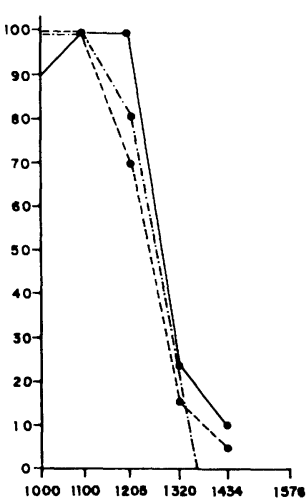

$\mathrm{CaO}\left(53,84^{\circ}\right)$

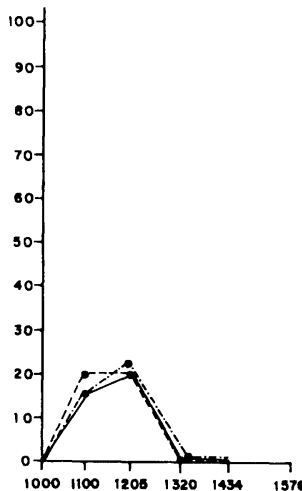

$\mathrm{S}\left(21,93^{\circ}\right)$

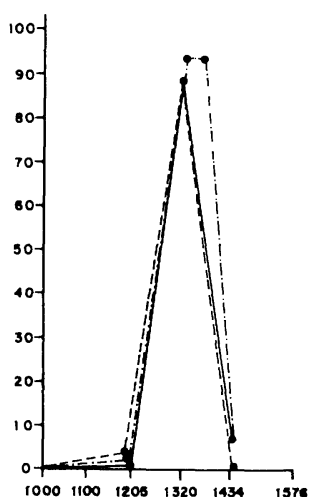

$\gamma-C_{2} S\left(29,68^{\circ}\right)$

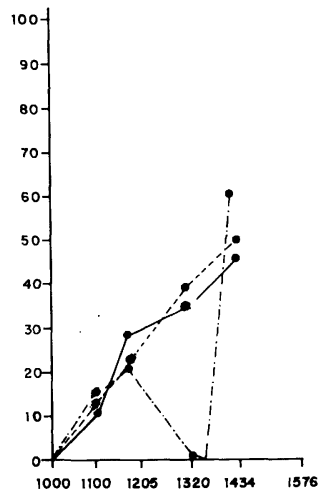

$\beta-C_{2} S\left(31,07^{\circ}\right)$

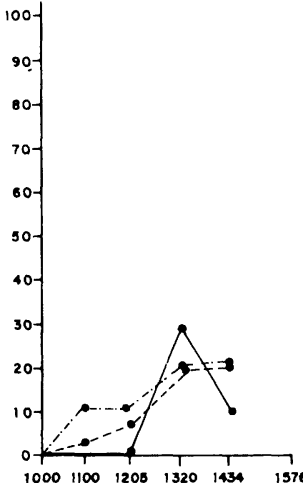

$\mathrm{C}_{2} \mathrm{~F}\left(33,33^{\circ}\right)$

Fig. 1.-Intensidades de los compuestos: $\mathrm{CaO}, \mathrm{SiO}_{2}, \gamma-\mathrm{C}_{2} \mathrm{~S}, \beta-\mathrm{C}_{2} \mathrm{~S}$ y $\mathrm{C}_{2} \mathrm{~F}$ para adiciones de $-5 \mathrm{C}_{2} \mathrm{~F},-\cdot-\cdot-10 \mathrm{C}_{2} \mathrm{~F}$ y -.. $15 \mathrm{C}_{2} \mathrm{~F}$ a $100 \mathrm{C}_{2} \mathrm{~S}$.

Fig. 1.-Intensity of compounds: $\mathrm{CaO}, \mathrm{SiO}_{2}, \gamma-\mathrm{C}_{2} \mathrm{~S}, \beta-\mathrm{C}_{2} \mathrm{~S}$ and $\mathrm{C}_{2} \mathrm{~F}$ for additions of $-5 \mathrm{C}_{2} \mathrm{~F}-\cdot-\cdot-10 \mathrm{C}_{2} \mathrm{~F}$ and $\cdots 15 \mathrm{C}_{2} \mathrm{~F}$ at $100 \mathrm{C}_{2} \mathrm{~S}$.

\section{INFLUENCIA SOBRE LOS SILICATOS DE LA ADICIÓN DE $\mathrm{Ca}_{3} \mathrm{Al}_{2} \mathrm{O}_{6}$}

En la (Fig. 2, $\mathrm{CaO}$ ), se puede observar que al aumentar la cantidad de $\mathrm{Ca}_{3} \mathrm{Al}_{2} \mathrm{O}_{5}$ en el crudo, desde 5 a 15 por cada 100 de $\mathrm{Ca}_{2} \mathrm{SiO}_{4}$, aumenta la velocidad de reacción de la cal para formar silicatos. Si comparamos esta gráfica con la Fig. 1, CaO vemos, sin embargo,

\section{INFLUENCE ON THE SILICATES OF THE ADITION OF $\mathrm{Ca}_{3} \mathrm{Al}_{2} \mathrm{O}_{6}$}

In the (Fig. 2, $\mathrm{CaO}$ ) it can be observed that to increase the cuantity of $\mathrm{Ca}_{3} \mathrm{Al}_{2} \mathrm{O}_{5}$ in the crude, from 5 to 15 for each 100 of $\mathrm{Ca}_{2} \mathrm{SiO}_{4}$ increases the velocity of reaction on the CaO to form silicates if we compare this graphic with the Fig. 1, CaOF we can see nevertheless that the 
que los efectos aceleradores son menores que los ocasionados por los ferritos. El efecto retardador del $\mathrm{Ca}_{2} \mathrm{SiO}_{5}$ sobre la reacción de formación de silicatos hace que se encuentre mayor cantidad de cristobalita a $1.205^{\circ} \mathrm{C}$ (Fig. 2, S) y que aun se detecte a $1.434^{\circ} \mathrm{C}$ en cantidades semejantes a los del caso anterior (Fig. 1, $\mathrm{C}_{2}$ F). Asimismo el $\mathrm{Ca}_{3} \mathrm{Al}_{2} \mathrm{O}_{6}$ retarda la formación del $\gamma-\mathrm{Ca}_{2} \mathrm{SiO}_{4}$ (Fig. $2, \gamma-\mathrm{C}_{2} \mathrm{~S}$ ) a $1.434^{\circ} \mathrm{C}$ y se detecta con menores intensidades. También se puede observar la menor cantidad de $\gamma-\mathrm{Ca}_{2} \mathrm{SiO}_{4}$ que se forma al aumentar en el crudo la proporción de $\mathrm{Ca}_{3} \mathrm{Al}_{2} \mathrm{O}_{6}$. La disminución del $\gamma-\mathrm{Ca}_{2} \mathrm{SiO}_{4}$ (Fig. 2, $\gamma-\mathrm{C}_{2} \mathrm{~S}$ ) para una adición del 15 de $\mathrm{C}_{3} \mathrm{~A}$ no afecta a la fomación del $\beta-\mathrm{Ca}_{2} \mathrm{SiO}_{4}$ (Fig. 2, $\beta-\mathrm{C}_{2} \mathrm{~S}$ ) y son, para dicha adición, ligeramente menores hasta $1.320^{\circ} \mathrm{C}$.

El $\mathrm{Ca}_{3} \mathrm{Al}_{2} \mathrm{O}_{6}$ (Fig. 2, $\mathrm{C}_{3} \mathrm{~A}$ ) solamente se detecta para crudos que contengan más del 15 de $\mathrm{C}_{3} \mathrm{~A}$, en proporción a 100 de silicato bicálcico. accelerating effects are smaller that those originated by the ferrites when. The temperatures are greater than the retardativ efect of the $\mathrm{Ca}_{2} \mathrm{SiO}_{5}$ on the reaction of the formation of silicates is the cause that there disgreater, quantity of cristobalite at $1.250^{\circ} \mathrm{C}$ (Fig. 2, S) and still is detected at $1.434^{\circ} \mathrm{C}$ in similar quantities of the former case (Fig. 1, $\mathrm{C}_{2} \mathrm{~F}$ ). In the same form $\mathrm{Ca}_{3} \mathrm{Al}_{2} \mathrm{O}_{6}$ retards the formation of gamma-Ca $\mathrm{SiO}_{2}$ (Fig. 2, $\gamma-\mathrm{C}_{2} \mathrm{~S}$ ) at $1.434^{\circ} \mathrm{C}$ and it is detected with less intensities. Also you can observe the less quantity of $\gamma-\mathrm{Ca}_{2} \mathrm{SiO}_{4}$ that it is formed to increase in to the crude the proportion of $\mathrm{Ca}_{3} \mathrm{Al}_{2} \mathrm{O}_{6}$. The diminutions of the gamma- $\mathrm{Ca}_{2} \mathrm{SiO}_{4}$ (Fig. 2, $\gamma-C_{2} S$ ) for addition of 15 of $C_{3} A$ does not at to the formation of the beta- $\mathrm{Ca}_{2} \mathrm{SiO}_{4}$ (Fig. 2, $\left.\beta-C_{2} S\right)$ and they are lightly minors for such addition only to $1.320^{\circ} \mathrm{C}$. The $\mathrm{Ca}_{3} \mathrm{Al}_{2} \mathrm{O}_{6}$ (Fig. 2, $\mathrm{C}_{3} A$ ) only is detected by crudes that contain more of the $15 C_{3} A$ in proportion to 100 of bicalcium silicate.

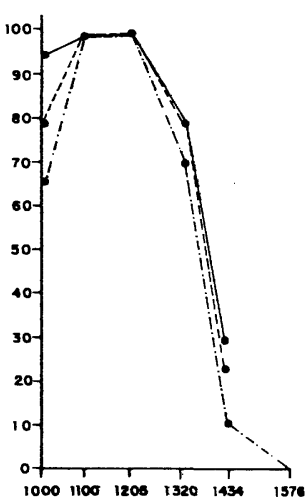

$\mathrm{CaO}\left(53,84^{\circ}\right)$

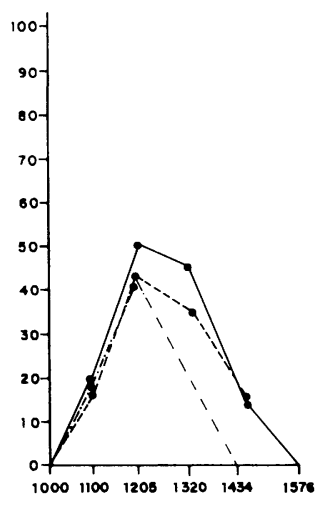

$S\left(21,93^{\circ}\right)$

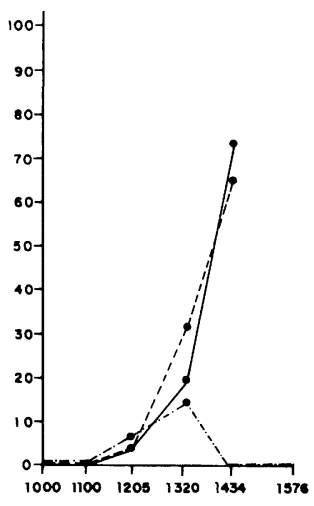

$\gamma-C_{2} S\left(29,68^{\circ}\right)$

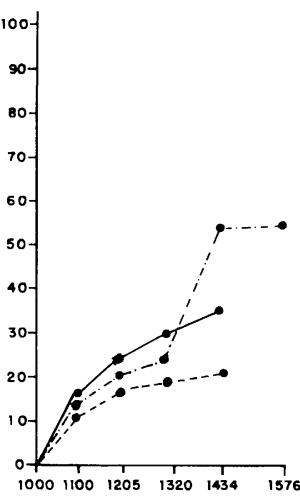

$\beta-c_{2} s\left(31,07^{\circ}\right)$

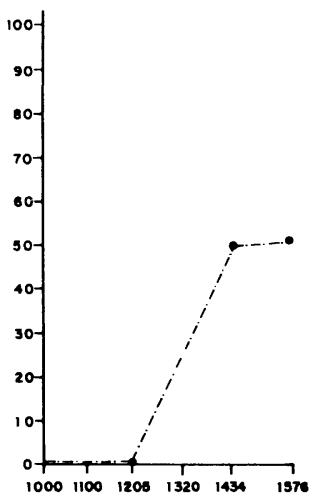

$\mathrm{C}_{3} \mathrm{~A}\left(33,15^{\circ}\right)$

Fig. 2.-Intensidades de los compuestos $\mathrm{CaO}, \mathrm{SiO}_{2}, \gamma-\mathrm{C}_{2} \mathrm{~S}, \beta-\mathrm{C}_{2} \mathrm{~S}$ y $\mathrm{C}_{3} \mathrm{~A}$ para adiciones de $-5 \mathrm{C}_{3} \mathrm{~A}, \ldots \cdot-\cdot-10 \mathrm{C}_{3} \mathrm{~A}$ y ... $15 \mathrm{C}_{3} \mathrm{~A}$ a $100 \mathrm{C}_{2} \mathrm{~S}$.

Fig. 2.-Intensity of compounds: $\mathrm{CaO}, \mathrm{SiO}_{2}, \gamma-\mathrm{C}_{2} \mathrm{~S}, \beta-\mathrm{C}_{2} \mathrm{~S}$ and $\mathrm{C}_{3} \mathrm{~A}$ for additions of $-5 \mathrm{C}_{3} \mathrm{~A}-\cdot-\cdot-10 \mathrm{C}_{3} \mathrm{~A}$ and -..- $15 C_{3} A$ at $100 C_{2} S$.

\section{INFLUENCIA SOBRE LOS SILICATOS DE LA ADICIÓN DE $\mathrm{Ca}_{4} \mathrm{Al}_{2} \mathrm{Fe}_{2} \mathrm{O}_{10}$}

Si comparamos las gráficas de la $\mathrm{CaO}$ (Figs. 1, 2 y $3, \mathrm{CaO}$ ) se observa que los crudos que contenían $\mathrm{Ca}_{4} \mathrm{Al}_{2} \mathrm{Fe}_{2} \mathrm{O}_{10}$ ocupan un lugar intermedio entre los que contenian $\mathrm{Ca}_{2} \mathrm{Fe}_{2} \mathrm{O}_{5}$ y $\mathrm{Ca}_{3} \mathrm{Al}_{2} \mathrm{O}_{6}$, siendo más próximos al $\mathrm{Ca}_{2} \mathrm{Fe}_{2} \mathrm{O}_{5}$. Con la cristobalita sucede lo mismo (Fig. $3, \mathrm{~S}$ ), no afectando tanto a la formación del $\gamma-\mathrm{Ca}_{2} \mathrm{SiO}_{4}$, cuya gráfica es más semejante a los crudos que contenían $\mathrm{Ca}_{2} \mathrm{Fe}_{2} \mathrm{O}_{5}$, ya que se conserva la temperatura del máximo a $1.320^{\circ} \mathrm{C}$ aunque las intensidades son menores. La gráfica (Fig. 3, $\beta-\mathrm{C}_{2} \mathrm{~S}$ ) nos indica que, igual que en los casos anteriores (Figs. 1 y $\left.2, \beta-C_{2} S\right)$, no hay influencias de las adiciones

\section{INFLUENCE ON THE SILICATES BY ADDITION OF FERRITES $\mathrm{Ca}_{4} \mathrm{Al}_{2} \mathrm{Fe}_{2} \mathrm{O}_{10}$}

If we compare the graphics of $\mathrm{CaO}$ (Fig. 1, 2 and $3-\mathrm{CaO}$ ) it is observed that the crudes that contained $\mathrm{Ca}_{2} \mathrm{Fe}_{2} \mathrm{O}_{5}$ and $\mathrm{Ca}_{3} \mathrm{Al}_{2} \mathrm{O}_{6}$ they are nearest to $\mathrm{Ca}_{2} \mathrm{Fe}_{2} \mathrm{O}_{5}$. With the cristobalite occurs the same (Fig. 3, S), it does not affect much to the formation of $\gamma-\mathrm{Ca}_{2} \mathrm{SiO}_{4}$ which graphic is more similar to the crudes that contained $\mathrm{Ca}_{2} \mathrm{Fe}_{2} \mathrm{O}_{5}$, it is because conserves the temperature of the maximum at $1.320^{\circ} \mathrm{C}$, although the intensities are minors. The graphic (Fig. 3, $\beta-C_{2} S$ ) shows us that in the same form that in the anterior cases (Fig. 1 and $2 \beta-C_{2} S$ ) there are not influences of the aditions on the quantity produced of 
sobre la cantidad producida de $\beta-\mathrm{Ca}_{2} \mathrm{SiO}_{4}$. En la Figura $3, \mathrm{C}_{4} \mathrm{AF}$ vemos que el $\mathrm{C}_{4} \mathrm{AF}$ aumenta para las concentraciones calculadas, más altas de $\mathrm{C}_{4} \mathrm{AF}$ en el crudo.
$\beta-\mathrm{Ca}_{2} \mathrm{SiO}_{4}$. In the Fig. 3, $\mathrm{C}_{4} \mathrm{AF}$ we see that the $\mathrm{C}_{4} \mathrm{AF}$ increases for the calculated concentrations, higher of $\mathrm{Ca}_{4} \mathrm{AF}$ in the crude.

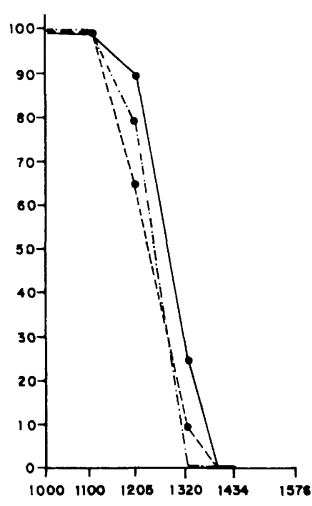

$\mathrm{CaO}\left(53,84^{\circ}\right)$

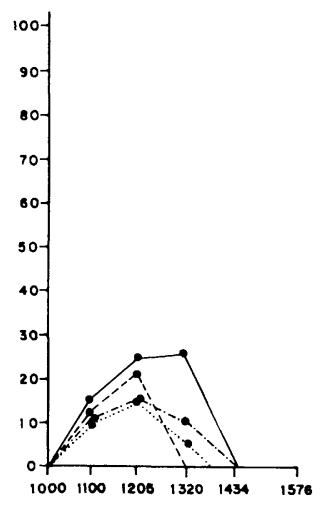

$S\left(21,93^{\circ}\right)$

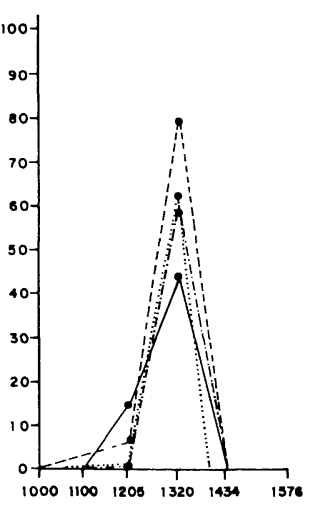

$\gamma-C_{2} S\left(29,68^{\circ}\right)$

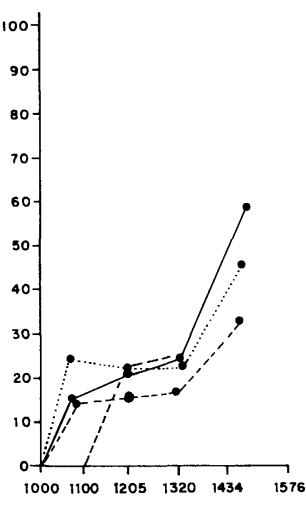

$\beta-C_{2} S\left(31,07^{\circ}\right)$

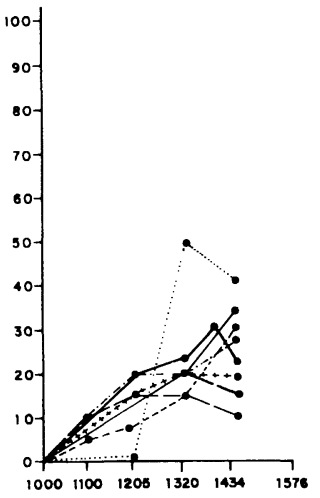

$\mathrm{C}_{4} \mathrm{AF}\left(33,88^{\circ}\right)$

Fig. 3.-Intensidades de los compuestos citados para adiciones de $-5 \mathrm{C}_{4} \mathrm{AF}, 10 \mathrm{C}_{4} \mathrm{AF},-\cdot-\cdot-15 \mathrm{C}_{4} \mathrm{AF}$ y $\cdots 20 \mathrm{C}_{4} \mathrm{AF}$ a $100 \mathrm{C}_{2} \mathrm{~S}$.

Fig. 3.-Intensity of compounds $-5 C_{4} A F, 10 C_{4} A F,-\cdot-\cdot-15 C_{4} A F$ and $\cdots-20 C_{4} A F$ at $100 C_{2} S$.

\section{INFLUENCIA EN LA FORMACIÓN DE SILICATOS DE ADICIONES DE $C_{3} A$ CON 5 DE $C_{4} A F, 10$ DE C 4 AF Y 15 DE C 4 AF}

El efecto combinado del $\mathrm{Ca}_{3} \mathrm{Al}_{2} \mathrm{O}_{6}$ y $\mathrm{Ca}_{4} \mathrm{Al}_{2} \mathrm{Fe}_{2} \mathrm{O}_{10}$ aumenta la velocidad de reacción de la cal (Fig. 4, $\mathrm{CaO}$ ) y sus valores son ligeramente inferiores a los de los casos anteriores (Figs. 1, 2 y 3, CaO). La formación de cristobalita (Fig. 4, S) aumenta ligeramente a $1.205^{\circ} \mathrm{C}$, y a $1.320^{\circ} \mathrm{C}$ ya no se detecta. Lo mismo sucede en el caso de la Fig. 2, $\mathrm{C}_{2} \mathrm{~F}$ y la formación del $\gamma-\mathrm{C}_{2} \mathrm{~S}$ con máximos a $1.320^{\circ} \mathrm{C}$, cuando deja de formarse la cristobalita (Fig. 4, S) y desaparece a $1.434^{\circ} \mathrm{C}$, crece para aumentos en la cantidad añadida de $\mathrm{C}_{4} \mathrm{AF}$, que

\section{INFLUENCE ON THE FORMATION OF SILICATES BY ADDITION OF ALUMINATE, FERRITE AND $C_{3} A$ with 5, 10 AND 15 OF $\mathrm{C}_{4}$ AF AT $100 \mathrm{C}_{2} \mathrm{~S}$}

The combinated effect of the $\mathrm{Ca}_{3} \mathrm{Al}_{2} \mathrm{O}_{6}$ and $\mathrm{Ca}_{4} \mathrm{Al}_{2} \mathrm{Fe}_{2} \mathrm{O}_{10}$, increases the reaction velocity of the $\mathrm{CaO}$ (Fig. 4, $\mathrm{CaO}$ ) which values are lightly minors to those before obtained (Fig. 1, 2, 3, $\mathrm{CaO}$ ).

The formation of cristobalite (Fig. 4, S) increases lightly; at $1.205^{\circ} \mathrm{C}$; and at $1.320^{\circ} \mathrm{C}$ it is not detected, the same that in the case of the Fig. 2, $C_{2} F$. The formation of $\gamma-C_{2} S$ with principals at $1.320^{\circ} \mathrm{C}$ when the cristobalite stops its-formation (Fig. 4, S) and 2 disappears

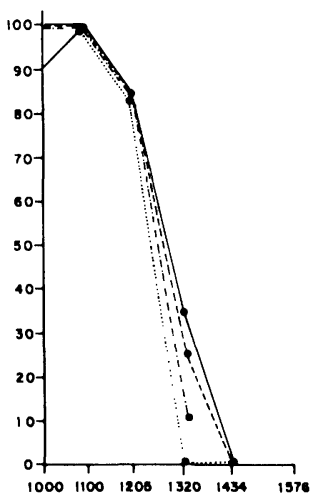

$\mathrm{CaO}\left(53,84^{\circ}\right)$

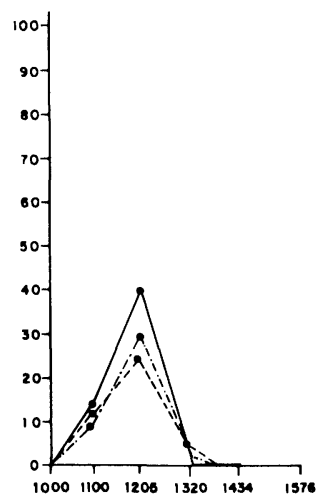

$\mathrm{S}\left(21,93^{\circ}\right)$

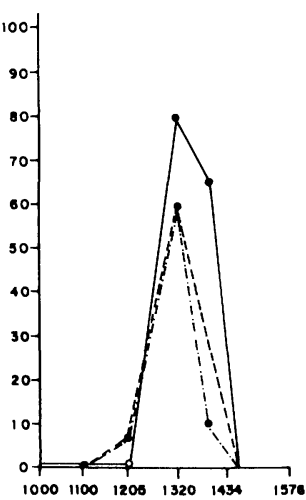

$\gamma-C_{2} S\left(29,68^{\circ}\right)$

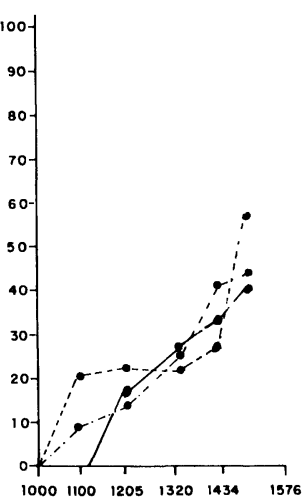

$\beta-C_{2} S\left(31,07^{\circ}\right)$

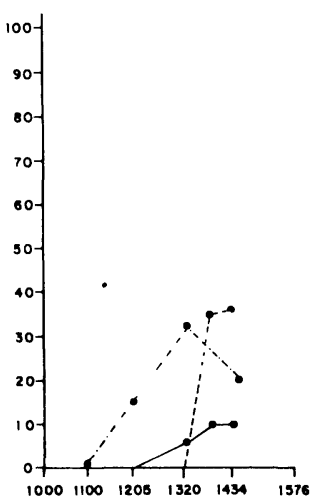

$C_{4} \operatorname{AF}\left(33,88^{\circ}\right)$

Fig. 4. - Intensidades de los compuestos $\mathrm{CaO}, \mathrm{SiO}_{2}, \gamma-\mathrm{C}_{2} \mathrm{~S}, \beta-\mathrm{C}_{2} \mathrm{~S}$ y $\mathrm{C}_{4} \mathrm{AF}$ para adiciones de $-5 \mathrm{C}_{3} \mathrm{~A}+5 \mathrm{C} \mathrm{C}_{4} \mathrm{AF}-\cdot-\cdot-$ $5 \mathrm{C}_{3} \mathrm{~A}+10 \mathrm{C}_{4} \mathrm{AF}$ y - . - $5 \mathrm{C}_{3} \mathrm{~A}+15 \mathrm{C}_{4} \mathrm{AF}$ a $100 \mathrm{C}_{2} \mathrm{~S}$.

Fig. 4.-Intensity of compounds: $\mathrm{CaO}, \mathrm{SiO}_{2}, \gamma-C_{2} \mathrm{~S}, \beta-C_{2} S$ and $\mathrm{C}_{4} A F$ for additions of $-5 C_{3} A+5 C_{4} A F-\cdot-\cdot-5 C_{3} A+$ $+10 \mathrm{C}_{4} \mathrm{AF}$ and $-. .5 \mathrm{C}_{3} \mathrm{~A}+15 \mathrm{C}_{4} \mathrm{AF}$ at $100 \mathrm{C}_{2} \mathrm{~S}$. 
inestabiliza la formación del $\gamma-\mathrm{C}_{2} \mathrm{~S}$. En la gráfica (Fig. 4, $\gamma-\mathrm{C}_{2} \mathrm{~S}$ ) no vemos cambios provocados por aumentos en la concentración del crudo con $\mathrm{C}_{4} \mathrm{AF}$, la tónica es similar a la de casos anteriores es decir hay independencia en la formación del $\beta$-silicato dicálcico de la concentración en el crudo de alúmina y hierro.

\section{INFLUENCIA SOBRE LOS SILICATOS DE ADICIONES DE $10 \mathrm{C}_{3} \mathrm{~A} Y$ 10-20 $\mathrm{C}_{4} \mathrm{AF}$ A $100 \mathrm{C}_{2} \mathrm{~S}$}

El aumento, al doble, en la concentración de $\mathrm{Ca}_{3} \mathrm{Al}_{2} \mathrm{O}_{6}$ no afecta a la velocidad de reacción del $\mathrm{CaO}$ (Fig. 5, $\mathrm{CaO}$ ) con la sílice. La cantidad formada de cristobalita (Fig. 5, S) es aún mayor que la del caso anterior (Fig. 4, S) y lo mismo sucede para el $\gamma-\mathrm{C}_{2} \mathrm{~S}$, es decir, que la mezcla actúa como inhibidor o retardador de la formación del $\gamma-\mathrm{C}_{2} \mathrm{~S}$. El aumento del $\mathrm{C}_{3} \mathrm{~A}$ en el crudo tampoco influye en la formación del $\beta-\mathrm{C}_{2} \mathrm{~S}$ (Fig. $5, \beta-\mathrm{C}_{2} \mathrm{~S}$ ). Las cantidades detectadas $\mathrm{Ca}_{4} \mathrm{Al}_{2} \mathrm{Fe}_{2} \mathrm{O}_{10}$ y $\mathrm{Ca}_{3} \mathrm{Al}_{2} \mathrm{O}_{6}$, son mayores al aumentar la proporción de dichos compuestos en el crudo (Fig. 4, $\mathrm{C}_{4} \mathrm{AF}$ y $\mathrm{C}_{3} \mathrm{~A}$ ). La disminución de la cristobalita (Fig. $5, \mathrm{~S}$ ) y del gamma silicato bicálcico (Fig. $5, \gamma-\mathrm{C}_{2} \mathrm{~S}$ ) es aparente y debida a una menor cantidad de dichos compuestos, por estar estos en menor proporción relativa en el crudo. at $1.434^{\circ} \mathrm{C}$ increases when increases the quantity added $\mathrm{C}_{4} A F$, that unstables the formation of $\gamma-C_{2} S$. In the (Fig. $4, \beta-C_{2} S$ ) we can't see changes caused by augmentation in the crude concentration with $C_{4} A F$, the process is similar to the cases seen before, there is independence in the formation of $\beta$-dicalcium silicate of the concentration into the crude of aluminaes and ferrites.

\section{INFLUENCE ON THE FORMATION OF SILICATES BY ADDITION OF ALUMINATES AND FERRITES: $10 \mathrm{C}_{3}$ A AND 10 TO $20 \mathrm{C}_{4}$ AF AT $100 \mathrm{C}_{2} \mathrm{~S}$}

The increase to the double in the concentration of $\mathrm{Ca}_{3} \mathrm{Al}_{2} \mathrm{O}_{6}$ doesn't affect to the velocity of the reaction of $\mathrm{CaO}$ (Fig. $5, \mathrm{CaO}$ ) with the $\mathrm{SiO}_{2}$. The formed quantity of cristobalita (Fig. 5, S) is less the before case (Fig. 4, S) and the same occurs for the $\gamma-C_{2} S$, namely that the mix acts as inhibitor or retarder of the formation of $\gamma-C_{2} S$. The increase of $C_{3} A$ in the crude doesn't affect in the formation of $\beta-C_{2} S$ (Fig. $5, \beta-C_{2} S$ ). The detected quantities of $\mathrm{Ca}_{4} \mathrm{Fe}_{2} \mathrm{O}_{7}$ and $\mathrm{Ca}_{3} \mathrm{Al}_{2} \mathrm{O}_{6}$ are greater to increase the proportion of such compounds into the crude (Fig. 4, $\mathrm{C}_{4} A F$ ). The disminution of cristobalite (Fig. 5, S) and gamma-bicalcium silicate (Fig. $5, \gamma_{-} C_{2} S$ ) is apparent and by the fact of a less possible quantity of formation of such compounds because these are in less relative proportion in the crude.
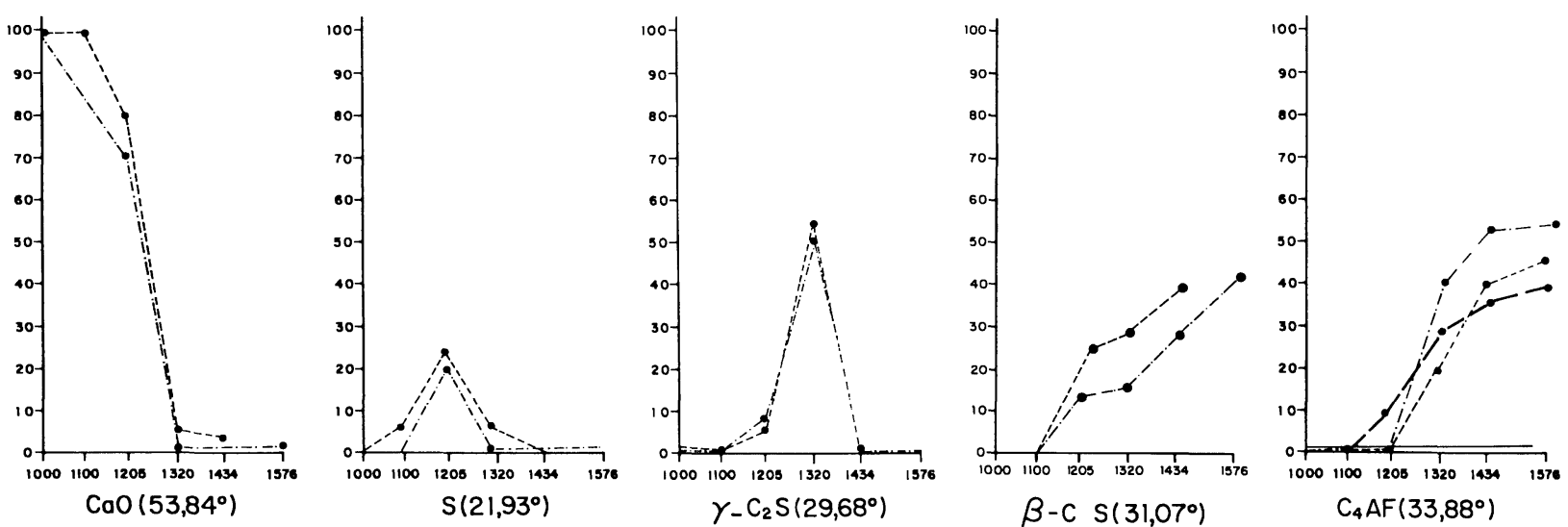

Fig. 5.-Intensidades de los compuestos: $\mathrm{CaO}, \mathrm{SiO}_{2}, \gamma-\mathrm{C}_{2} \mathrm{~S}, \beta-\mathrm{C}_{2} \mathrm{~S}$ y $\mathrm{C}_{4} \mathrm{AF}$ para adiciones de $-\cdots 10 \mathrm{C}_{3} \mathrm{~A}+10 \mathrm{C}_{4} \mathrm{AF}$ y $-\cdot-\cdot-10 \mathrm{C}_{3} \mathrm{~A}+20 \mathrm{C}_{4} \mathrm{AF}$ a $100 \mathrm{C}_{2} \mathrm{~S}$.

Fig. 5.-Intensity of compounds: $\mathrm{CaO}, \mathrm{SiO}_{2}, \gamma \mathrm{C}_{2} \mathrm{~S}, \beta-\mathrm{C}_{2} \mathrm{~S}$ and $\mathrm{C}_{4} \mathrm{AF}$ for additions of $-\cdots 10 \mathrm{C}_{3} \mathrm{~A}+10 \mathrm{C}_{4} \mathrm{AF}$ and $-\cdot-\cdot-10 C_{3} A+20 C_{4} A F$ at $100 C_{2} S$.

\section{CONSIDERACIONES}

Se da una panorámica de las reacciones de clinkerización previas del clínker portland sin tener en cuenta nada más que los efectos sobre la producción del silicato bicálcico,

\section{CONSIDERATIONS}

It presents a view of the reactions of the previous clinkeration of the porland clinker it has in cosideration only the effects on the production of the bicalcium silicate, from the 
parece ser de los resultados obtenidos, que si bien los ferritos y aluminatos son

estabilizantes de la forma beta, un aumento de estos componentes no mejora precisamente las propiedades del clínker como estabilizantes de dicha forma. Este estudio está dirigido a observar los efectos de distintos componentes sobre la hidraulicidad del $\beta-C_{2} \mathrm{~S}$. Sin embargo todos los casos estudiados indican que las formas más hidráulicas del silicato bicálcico son las más puras y que cualquier adicción de cualquier otro compuesto químico, fase o componente mineralógico que se le añada no mejora sus propiedades hidráulicas (8).

Sería muy conveniente realizar estudios paralelos sobre las alitas.

\section{AGRADECIMIENTO}

Los autores agradecen a la Dirección General de Investigación Científica y Técnica la colaboración económica al proyecto, del cual este trabajo es una parte. Así como a Bernardo Torroja, del ICCET, la traducción al inglés de este trabajo. result obtained it seems, that it the ferrites and aluminates are equilibrators of the form beta, an increase of these compounds doesn't improve the properties of the clinker as equilibrators of such form. This study is made to observe the effects of different compounds about the hydraulicity of $\beta-C_{2} S$. Nevertheless the put in manifestation that the forms more hydrauilics of the bicalcium are the most pures and that other adition that can be added don't improve the hydraulic properties (8).

It would be very useful to realize parallel studies on the alites.

\section{ACKNOWLEDGEMENTS}

Authors are grateful for the economic collaboration of the General Direction of Scientific and Tecnical Research to the project, this paper is part of it. Also our gatitude to Bernardo Torroja, of ICCET, for the translation into english of this paper.

\section{BIBLIOGRAFIA}

(1) Polimorphism of dicalcium silicate S. L. Sarkar World Cement Technology, 20-31, 1980.

(2) Polymorphism and transformation of $\beta-\mathrm{Ca}_{2} \mathrm{SiO}_{4}$. F. Hanic, I. Kapralik, V. Figus, J. Stracelsi. Trans. J. Ceram. Soc., 82, 205-207, 1983.

(3) Zur Umwandlung der Modifikationen beta-gamma des Dicalciumsilikats Von S. Chromy. Nr8, 382-389, 1970 ZementKalk-Gips.

(4) Existenzbereiche und Stabilisierung von Hoctemperaturmodifikationen des dicalciumsilicates. Zement-Kalk-Gips. H. E. Schwiete, W. Krönert y K. Deckert, 359-366, N. ${ }^{\circ}$ 9, 1968.

(5) Die Stabilitätsbereiche der Modifikationen des Dicalcium silikats. Hans Lehmann; Konrad Niesel y Peter Thomann, Tonindustrie Zeitumg. N. ${ }^{\circ}$ 6, 197-209, 1969.

(6) Synthesis of dicalcium silicate and tricalcium silicate phases. Surendra Nath Ghosh 1.12-16.2. The VII International Congress the Chemistry of Cement. 1980, Paris.

(7) The Solid Solution Ranges of $\mathrm{Al}_{2} \mathrm{O}_{3}$ and $\mathrm{Fe}_{2} \mathrm{O}_{3}$ in the High Temperature Modifications of $2 \mathrm{CaO}_{3} \mathrm{SiO}$. Goro Yamaguch 35-36 Review of the General Meeting, 1971. Tokio.

(8) Influencia de los elementos de transición y algunos elementos representativos en los polimorfos del silicato bicálcico. Ana Triviño. Tesis doctoral 1985. Madrid. Universidad Complutense. Facultad de Farmacia. 